\title{
Introduction
}

\section{WHAT IS A MOTORWAY?}

Technically, a motorway can be defined as a road that has been specially designed and constructed for motor traffic, and which is provided, except at special points or temporarily, with separate carriageways for the two directions of traffic, separated from each other either by a dividing strip not intended for traffic or, exceptionally, by other means. ${ }^{1}$ Additionally, a motorway does not cross at grade with any road, railway or tramway track, or footpath.

The concept of the motorway can be traced initially to Italy. According to Italian scholars Ragazzi and Greco (2005), the word 'autostrada' was first coined in 1922 by the engineer Pietro Puricelli in his project 'Road Network for Motor Vehicles' in which he outlined plans for the 'Autostrada dei Laghi', the world's first intercity motorway. The word 'autostrada' has subsequently been translated into a variety of languages (so we find 'autoroute' in French, 'autopista' in Catalan and Spanish, 'autoestrada' in Portuguese, 'Autobahn' in German, and so on).

In English, however, there is some confusion regarding the term to define high-capacity roads of this type. In addition to 'motorway', a range of terms have been adopted in different countries. Thus, we find in common use 'expressways', 'freeways', 'superhighways', 'parkways', 'thruways', 'throughways' and 'highways'. However, most of these terms are used ambiguously and often simply refer to conventional roads, which can be confusing for international readers. For instance, a 'highway' often refers to a public road that all may use, especially one that connects towns and cities. ${ }^{2}$ The American term 'parkway' denotes a broad roadway bordered and, often, divided with plantings of trees, bushes and grass. ${ }^{3}$ Indeed, both terms are frequently used to denote higher-quality roads or dual carriageways but they do not necessarily satisfy the requirements of a high-capacity road or motorway, as identified in this book.

Motorways should therefore be considered synonymous with any of these terms only if what we have in mind is a major arterial divided road with two or more lanes of traffic in each direction, with opposing traffic separated by a median strip and from which any grade crossings have 
been eliminated. Additionally, the road should have controlled entries and exits, and advanced design eliminating steep grades, sharp curves and other hazards and inconveniences to driving. ${ }^{4}$ Likewise, the British term 'expressway' is closely linked with this concept, although it does not fully conform to all the features of a motorway. They are described in some dictionaries as divided highways for through traffic, with full or partial control of access, and generally with overpasses or underpasses at intersections; however, in others, in reference to the American definition, they are defined simply as urban motorways. 5 'Freeways', for example, can be defined as multiple-lane divided highways with fully controlled access, as by 'cloverleaves', or simply as roads without toll charges. ${ }^{6}$ And 'throughways' are described as major roads or as motorways or highways. ${ }^{7}$ Therefore, in this book I opt to use the term 'motorway', and while this choice might seem arbitrary to some, it can to all intents and purposes be considered synonymous with terms with which you might be more familiar.

\section{TOLLS VERSUS VIGNETTES?}

Tolls and vignettes are fees paid by the users of infrastructure. The main difference lies in the fact that the former are usually distance-related and, therefore, vary according to the use made of the infrastructure (number of kilometres driven), while vignettes are usually time-related, giving the user the right to use the infrastructure for a given period of time (which might be for one day, one week, one month or one year). As such, tolls are more closely related to the use of the infrastructure and vignettes are more closely associated with the right of access. The two charges can vary according to vehicle features (usually number of axles and weight), the geographical area, the category of emissions, and so on.

\section{HOW IS PRIVATISATION INTERPRETED IN THIS BOOK?}

Here, 'privatisation' is broadly understood to include those policies in which the involvement of the private sector increases in terms of the ownership (asset sales), production (building and management) and/or the long-run financing (user payments) of motorways. As such, the growth in number of privatisation policies need not necessarily respond solely to an increase in asset sales to the private sector, but may involve the introduction of user financing to fund infrastructure investments and motorway 
management, as has been the case recently in many European countries. Therefore, here privatisation is considered as potentially affecting any or all of the following three dimensions:

1. Ownership (asset sales). Privatisation of existing motorways (owned and managed by the State) or the sale of established publicly owned concessionaires (corporate companies controlled by the State).

2. Production (public-private partnerships, PPPs). Creation and/or management of a motorway network through the awarding of PPP contracts to the private sector.

3. Private financing. Privatisation of the long-run financing of a motorway, whereby users are charged as a means of recovering investments and/or operation and maintenance costs.

\section{PLAN OF THE BOOK}

Tracing the origins of today's motorways and understanding their past models of ownership, management and financing are necessary conditions for analysing the reforms implemented in recent decades and, thus, for understanding the historical context of recent trends towards privatisation. This book, therefore, starts by describing the history of roads and motorways in Europe (Chapter 1), and provides insights into their origins and development over the past century. After accounting for differences in the ownership, management and financing models adopted in the twentieth century, the book reviews the current wave favouring privatisation, typified by the sale of publicly owned motorway companies, the increasing number of PPP contracts being awarded for the development and management of motorways, and the introduction of user financing in European motorways (Chapter 2).

To understand better the theoretical background to privatisation and regulation policies, Part II identifies the fundamental drivers of privatisation and regulation in the motorway sector (Chapter 3 ) and discusses the elements that are critical in the design of any public-private collaboration (Chapter 4), paying particular attention to the introduction of traffic risk mitigation mechanisms (Chapter 5). An additional chapter is devoted to the unfortunate outcomes of privatisation policies and here the most common reasons for failure are discussed (Chapter 6).

Part III undertakes a study of the history of three pioneers of motorway privatisation: Spain (Chapter 7), Italy (Chapter 8) and France (Chapter 9). These three experiences are reviewed in detail in order to highlight 
the elements that have contributed to the success or failure of motorway privatisation.

Part IV of the book undertakes an evaluation of privatisation policies, drawing on the existing literature on PPPs, focused above all on the European experience (Chapter 10). This chapter seeks to offer a direct response to what we know about motorway privatisation. Finally, the last chapter provides the reader with a summary of the book's main conclusions (Chapter 11).

\section{NOTES}

1. This definition is used by the European Union and was established, for instance, by the Directive 1999/62/EC on the charging of heavy goods vehicles for the use of motorways.

2. Definition taken from the Collins Dictionary.

3. Definition taken from the Collins Dictionary.

4. This is how the Encyclopedia Britannica defines 'expressway'. This definition fits well with the notion of 'motorway' that is used throughout this book.

5. The first definition is taken from the Collins Dictionary and the second from the Oxford English Dictionary in reference to the North American usage of 'expressway'.

6. See the Collins Dictionary definition.

7. See Oxford English Dictionary definition. 
Daniel Albalate - 9781781953938 Downloaded from PubFactory at 04/26/2023 01:16:01PM via free access 